\title{
Cooperation Model of "Tampan"(dividing profit based on the agreement) and "Ounce" (cooperation model based on the ounce scale in the Coconut Sugar Production)
}

\section{The Study of Coconut Sugar Produsen in Karang BendoVillage Ponggok District Blitar Regency)}

Oleh:

Mochmad Anis ${ }^{1)}$, Endah Masrunik ${ }^{2)}$ Anam Miftakhul Huda ${ }^{3)}$

Economic Faculty of Islamic Balitar University

Email: mochamadanis01@gmail.com ${ }^{1)}$, endahmasrunik@gmail.com ${ }^{2)}$

a6.asix6@yahoo.co.id ${ }^{3)}$

\begin{abstract}
Cooperation is an action in the job which is done by two or more people to gain the same purpose. This researh aims to know about coconut sugar production in the Karangbendo Village Ponggok District Blitar Regency.The kind of research which is used is qualitative research with phenomenology approach. This approach focused on the interview that is done deeply about the phenomena which is experienced by the informan. Subject in the research is a coconut sugar production while the object is a cooperation between the owner of coconut sugar producer. The data analysis technique descriptve analysis. The result of this reserch is there are two kinds of cooperation between the owner and the producer; they are "tampan" and "ounce". Each cooperation model has their own differences.
\end{abstract}

Keyword: Cooperation Model, Tampan, Ounce

\section{INTRODUCTION}

Humans as social beings will not be able to meet their own needs without help from other humans. Humans need to work together with other humans so that their needs can be fulfilled. One important human need is the need in the economic field. In the economic field, people will not feel satisfied if they only fulfill their primary needs so that they will certainly try to meet other needs. In order to achieve it they can work together with people who have the same goals as them so that their wishes will be more quickly achieved 
JOSAR, Vol. 1 No. 1 March 2019; p-ISSN: 2502-8251; e-ISSN: 2503-1155

Copyrights@ Balitar Islamic University, Blitar-Indonesia https://ejournal.unisbablitar.ac.id/index.php/josar

Coconut trees (cocos nucivera $\mathrm{L}$ ) are plantations of the palmae family, which can be utilized almost all of them. Coconut trees are known as trees that have a thousand benefits because all parts of the coconut tree from the stem to the leaves can be utilized. One result of processing these trees is coconut sugar. Coconut sugar is the result of cooking coconut tree sap. Coconut sugar does have great potential to increase regional or national income. This is inseparable from the role of traditional coconut sugar farmers in each region because they are willing to risk their safety to take palm juice from the coconut tree which is the raw material for making coconut sugar. They are willing to climb coconut trees every day without a single safety device to get the sap water which will then be cooked into coconut sugar. One area in East Java that is a producer of brown sugar is Blitar district. The northern Blitar region is indeed known as the center of the coconut sugar industry. The abundant production of coconut sugar contributes to the coconut sugar industry which is widely developed in Blitar district.

One area in Blitar regency which is a producer of brown sugar is Karangbendo village. This is because Karangbendo village has fertile land and there are still many coconut trees that grow. Therefore, many people in the village of Karangbendo who utilize the results of coconut tree sap to be made into brown sugar even though to take coconut palm juice the risk is quite large because it is not impossible to have an accident when taking sap, such as falling from coconut trees and others. Because of the large risk, many coconut tree owners do not dare to climb it themselves so that in order to obtain additional income they work together with other people who dare to take the sap water with a profit sharing system.

Profit sharing in Karangbendo village can be done by two methods, the ounce method and the "tampan" method, but the most commonly used method is the handsome method. The ounce method that processes the sap is the recipient, while the owner will get the portion in the form of sugar according to the agreement, while the handsome method will get the sap 
according to the agreement, which will then be processed into coconut sugar. For the owner, the handsome method is considered more profitable than the ounce method even though in the "tampan" method the tree owner must pay more for the process of making coconut sugar but the amount of income received is much greater.

Income is closely related to costs (Huda, Anam Miftakhul. Farida, 2018). Revenue can be interpreted as the results obtained from company activities in a period. While the cost or cost is the sacrifice of economic resources that are measured in units of money that have occurred or are likely to occur to achieve certain goals (Bustami, 2010). Definition of costs in the broadest sense is the sacrifice of economic resources measured in units of money, which have occurred or which are likely to occur for certain purposes (Mulyadi, 2014: 8).

Revenues arising from economic events include the sale of goods, sale of services, use of company assets by other parties that generate interest, royalties and dividends. Sources of income can be classified into two, namely income from company operations and income from nonoperating companies. In coconut production income is obtained from the sale of goods that have been produced, namely coconut sugar. So, the income received by coconut sugar producers can be categorized as operating income. The size of the income obtained from a business is influenced by the size of the production and the prevailing price (Mugiono, 2014: 29).

The discussion of costs in accounting is found in cost accounting. Cost accounting is a branch of economics that focuses on the finances of a company or agency. Cost accounting is part of the science of financial accounting and management accounting. Accounting in general can be divided into two types, financial accounting and management accounting (Huda \& Martanti, 2018). Cost accounting is not separate from the two types, but part of the two types. Cost accounting is the process of recording, classifying, summarizing and presenting the costs of making 
JOSAR, Vol. 1 No. 1 March 2019; p-ISSN: 2502-8251; e-ISSN: 2503-1155

Copyrights@ Balitar Islamic University, Blitar-Indonesia https://ejournal.unisbablitar.ac.id/index.php/josar

and selling products or services, in certain ways, and interpreting them (Mulyadi, 2014: 7).

Equipment is one of the important elements in the production process of goods, as well as the production of coconut sugar. Equipment is assets or fixed assets owned by the company. Fixed assets are tangible goods that are relatively permanent in nature and are used in the normal activities of the company, not for sale (Rudianto, 2012). Fixed assets can also be interpreted as tangible assets owned by companies that are used to produce or supply goods or services that can be used for more than one accounting period (Kieso, 2007). Records used by companies to produce goods will incur costs for the company. These costs can be charged to the cost of goods or can also be recorded in bookkeeping as a deduction from income if the company is engaged in services. Costs incurred by equipment are equipment depreciation costs. Depreciation is the allocation of the acquisition price of a fixed asset to the accounting period that enjoys the benefit of the property, plant and equipment. There are 3 factors that need to be considered in determining the depreciation expense for each period, namely the acquisition price, residual value (residual) and estimated useful life (Rudianto, 2012).

The problem faced by the owner if using a handsome method is the handsome method which is now divided differently. The handsome method in the village of Karangbendo which used to be the distribution of sap between the beneficiary and the same owner, 7: 7 has now changed to 8: 7 or 10: 8. This is because the number of workers is decreasing so that the owners find it difficult to find a donor. This change causes the owner's income to be smaller than the income of the seller. Therefore the owner must be more careful in choosing the handsome method used.

The problem is also with the ounce method. The ounce method is considered to be more beneficial to the beneficiary than the tree owner. This is because the production of coconut sugar in the ounce method is mostly owned by the beneficiary. The amount of coconut sugar in the 
owner of the tree is too little compared to the sugar of the part of the tree. Usually one coconut tree can produce 5 ounces of sugar while in the ounce method the owner only gets 1 ounce of sugar for each tree. The ounce method is the last option for tree owners if there are no more people who want to use the "tampan" method.

Based on the description above, this study was conducted to determine the cooperation model on coconut sugar production in the village of Karangbendo, Ponggok District, Blitar Regency.

\section{II.RESEARCH METHODS}

This research is a descriptive qualitative study with a phenomenological approach. Qualitative research is research whose research findings are not obtained through statistical procedures or other forms of calculation. This procedure produces findings obtained from data collected using various means. Facilities include observation and interviews, but can also include documents, books, video tapes, and even data that has been calculated for other purposes, such as census data. Whereas phenomenology is a view that emphasizes the focus of human subjective experiences and world interpretations. Phenomenology research tries to explain or reveal the meaning of a concept or phenomenon of experience based on awareness that occurs in several individuals (Moleong, 2007: 14). So, in phenomenology research the most important thing is the interview conducted in depth to get as much detailed information as possible from the informant about the phenomenon they experienced.

The selection of informants is a very important element in qualitative research because informants will provide the data needed by researchers to solve problems in their research. In this study, informants were determined by purpose techniques, namely the technique of selecting informants according to certain criteria according to what had been determined according to the research topic. The data analysis 
JOSAR, Vol. 1 No. 1 March 2019; p-ISSN: 2502-8251; e-ISSN: 2503-1155

Copyrights@ Balitar Islamic University, Blitar-Indonesia https://ejournal.unisbablitar.ac.id/index.php/josar

technique used in this study is qualitative analysis. Descriptive qualitative analysis was used to explain the results of research on the cooperation model on coconut sugar production in Karangbendo village.

\section{III.RESULTS AND DISCUSSION}

This research was conducted in the village of Karangbendo, Ponggok District, Blitar Regency. The village still grows a lot of coconut trees so that many people process palm sugar into coconut sugar. Many people in the village of Karangbendo have coconut trees but don't dare to take their own dreams so they collaborate with the surrounding tigers. In this study, the results showed that in coconut sugar production, producers in the village of Karangbendo used two models of cooperation, namely a hands-on model of cooperation and an ounce of cooperation model. The two models have differences in the technical work and the distribution of the results so that this will determine the benefits that will be obtained by both tree owners and beneficiaries.

The method of cooperation chosen between tree owners and the beneficiary will indeed determine their income. This is in accordance with the results of a study by Siti Khotimah et al (2014: 52) which states that one of the factors that influence the income of coconut sugar producers is the sharing system or cooperation between tree owners and the beneficiary. The results of his research also state that the income of the beneficiary in the sugar-sharing system is higher than the income of the beneficiary with the system for the sap. This means that the income of tree owners on the sugar-sharing system (Ounces) is less than income with the share of the net income (tampan). Therefore, coconut sugar producers, both the party owner and the beneficiary, must choose the right cooperation model so that no party feels disadvantaged because the purpose of working together is to get mutual benefits. 
JOSAR, Vol. 1 No. 1 March 2019; p-ISSN: 2502-8251; e-ISSN: 2503-1155

Copyrights@ Balitar Islamic University, Blitar-Indonesia https://ejournal.unisbablitar.ac.id/index.php/josar

\section{Cooperation Model OF "TAMPAN"}

"Tampan" is a collaboration between tree owners and beneficiaries with the profit sharing according to the agreement. The results of the distribution will be processed into coconut sugar. The "tampan"agreement that is used will determine the income that will be received by coconut sugar farmers, both the beneficiary and the owner. This is because in the "tampan" cooperation there are differences in the division of labor between tree owners and the beneficiary so that it will also cause differences in the costs incurred because these costs are their respective obligations. This is confirmed by Mr. Wakid as follows:

If you work together, "tampan" equipment for picking up roomie, such as knife of sap taker, tubers and raffia, is borne by the donor, so the costs incurred by the donor are bigger. If the owner lives only processing roomie]

From the statement above, a table of differences can be made between tree owners and the beneficiaries as follows:

Table 1 Differences in Division of Work and Costs for "Tampan" Cooperation

\begin{tabular}{|c|c|}
\hline Producen of Tree owner & Produser of Sap Taker \\
\hline \multirow[t]{2}{*}{$\begin{array}{l}\text { 1. Proccessing roomie to be } \\
\text { sugar } \\
\text { What we need: } \\
\text { - container } \\
\text { - fuel } \\
\text { - cooking utensils }\end{array}$} & $\begin{array}{l}\text { 1. Taking roomie } \\
\text { equipment: } \\
\text { - Knife for taking sap } \\
\text { - Bumbung (cyliner } \\
\text { bamboo) } \\
\text { - Rafia rope }\end{array}$ \\
\hline & $\begin{array}{l}\text { 2. Pocessing roomie to be } \\
\text { sugar } \\
\text { What we need: } \\
\text { - container } \\
\text { - fuel } \\
\text { - cooking utensils }\end{array}$ \\
\hline
\end{tabular}

Skource:data frokm tue rsearcher

Based on the table above, it is known that in the "tampan" method tree owners only process the sap from the division only while the 
beneficiary in addition to processing the sap from the distribution also must take the sap each day. Equipment for taking roomie is also needed so that the costs incurred by the donor will be greater than the costs incurred by the tree owner.

The distribution of roomie is carried out alternately between the dancer and the owner. The distribution agreement of the room is calculated in units of days. For example, if the agreement between the seller and the owner is a tompo 7: 7, the reseller will receive the roomie for 7 days, followed by the owner who also receives roomie for 7 days later and so on. This is in accordance with what was revealed by Mr. Wakid, one of the collectors in Karangbendo village who used a handsome cooperation method:

If "tampan", the roomie can take turns so it doesn't work every day for coconut sugar production. For example, this week I thought my part then the next week, I thought that the part of Mrs. Tukini would continue to take turns]

From the description above can be made a chart that describes the process of "tampan" cooperation, namely as follows:

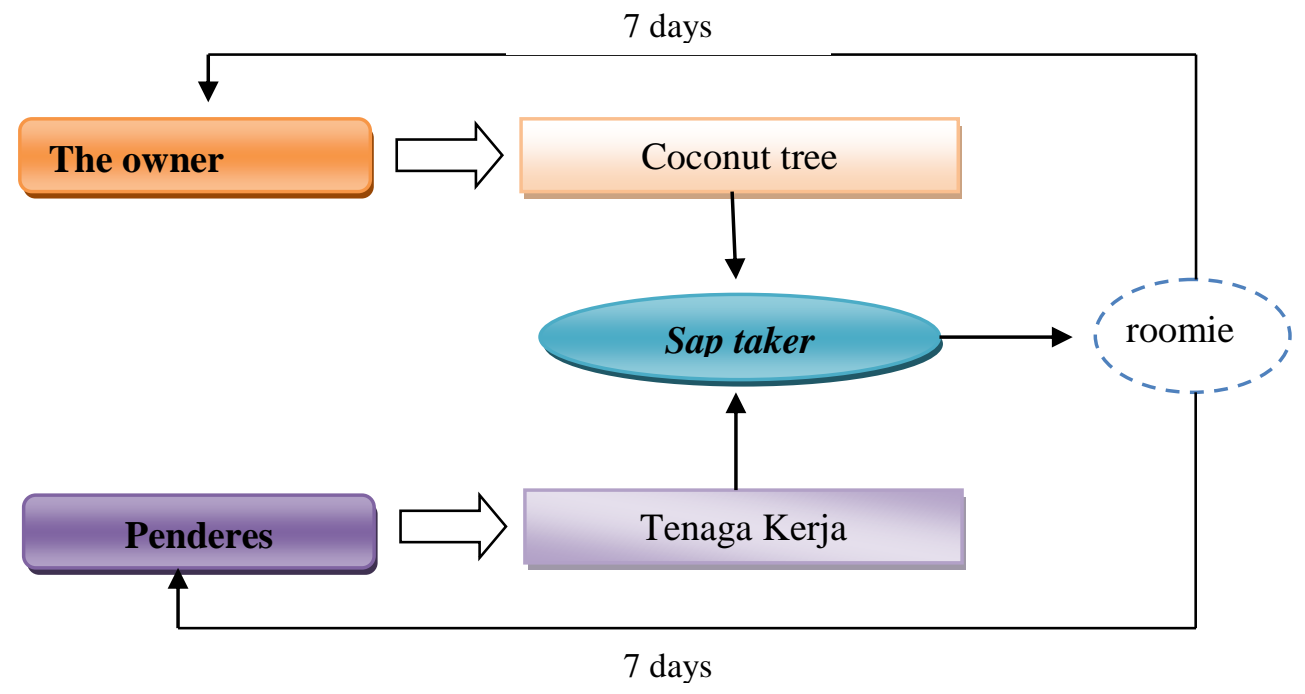

Picture I Tampan Model of Cooperation 
JOSAR, Vol. 1 No. 1 March 2019; p-ISSN: 2502-8251; e-ISSN: 2503-1155

Copyrights@ Balitar Islamic University, Blitar-Indonesia https://ejournal.unisbablitar.ac.id/index.php/josar

The picture above is "tampan" cooperation model with a 7: 7 "tompo" (accepting) deal. The tampan agreement in Karangbendo village varies from 7: 7, 8: 7 and 10: 8. Tompo 7: 7 means to get a 7-day collection and get 7 days for the owner. Whereas "tampan" 8: 7 means the 8 days part of the seller and the 7-day owner's share. Likewise at "Tompo" 10: 8 means roomie for 10 days for the tapers and 8 days for the owner. With the same "tompo" agreement that is 7: 7, the income of both will be the same but in a different "tampan" agreement, the amount of their income will also be different. At "Tompo" 8: 7 and 10: 8 the total income of the owner will be smaller than that of the donor.

\section{Ounce Cooperation Model}

The method of cooperation used by producers in the village of Karangbendo besides "tampan" is the ounce method. The ounce method is a method of cooperation between tree owners and where the beneficiary processes all the results while the owner will receive a portion of the sugar yield. For tree owners, the ounce method is a choice that must be used if you have not found a surfer who uses a handsome method. This was confirmed by lbu Kirah as the owner of the coconut tree who used the Ounce method in the following interview excerpt:

For my coconut tree I finally used the ounce method because looking for people who want to use "tampan" ones does not find them so instead of not taking them they will be forced to use the ounce method].

The same statement was also expressed by lbu Sriah who was also forced to use the ounce method in the quotation of the following interview:

Now looking for people who want to use the "tampan" method is difficult. It is difficult to start instead of harvesting coconuts, I better use the ounce method because when I wait for the coconut harvest, the time is long and the price of the coconut is cheap.

From the statement above, it can be concluded that the choice of ounce method used by tree owners is done if there are no more people who want to use the "tampan" method. On the ounce working model, the 
JOSAR, Vol. 1 No. 1 March 2019; p-ISSN: 2502-8251; e-ISSN: 2503-1155

Copyrights@ Balitar Islamic University, Blitar-Indonesia https://ejournal.unisbablitar.ac.id/index.php/josar

rescuer will take his coconut palm juice and the beneficiary will process all the results of the sap obtained into coconut sugar so that the owner does not need to process the sap into sugar. The owner will benefit from the sugar he receives from the tapers usually at 1 ounce per tree every day. If the owner has 10 trees, the owner will get $1 \mathrm{~kg}$ of sugar per day. This was confirmed by Mr. Sutres on the following quote from his vice president:

If I don't wear "tampan", use ounces. If ounces that take the juice of the sapper that produces nira are also beneficiaries, the tree owner gets some of the sugar, so ounces are actually like rent but the payment using sugar does not use money. The division of each coconut tree owner gets one ounce of sugar every day but usually the owner takes part of it once a month.

From the description above, a chart can be drawn which describes the cooperation of ounces in the production of coconut sugar as follows.

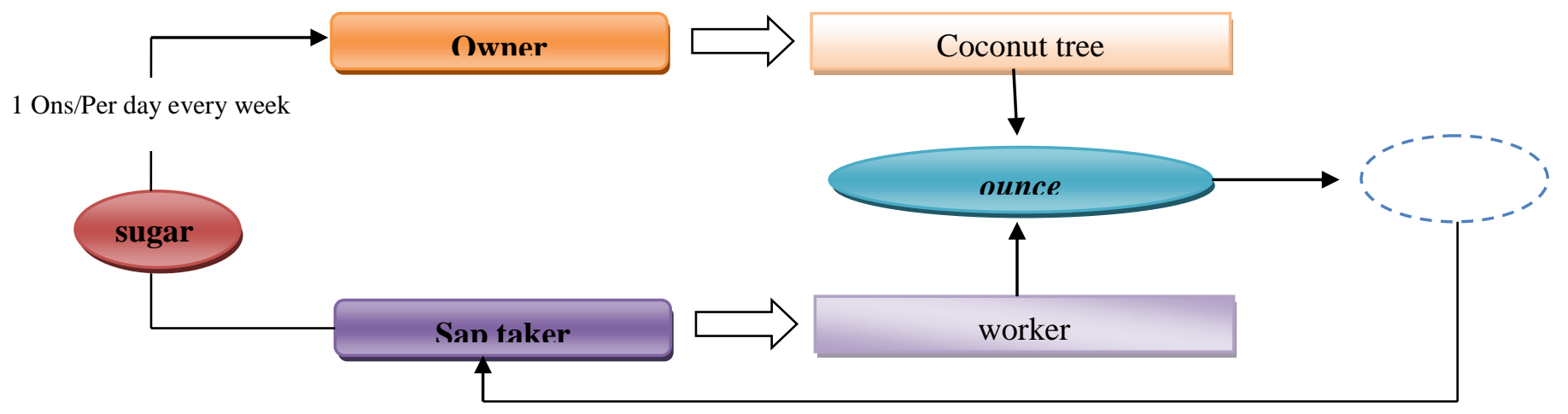

.picture 2 Ounce cooperation model

\section{CONCLUSION}

The cooperation model used by coconut sugar producers in Karangbendo village is of two types, namely the working model is "tampan" and the ounce of cooperation model. In a cooperation, tree owners and beneficiaries both produce coconut sugar while the ounce cooperation model that produces coconut sugar is only the party of the 
taster. The working model of the "tampan" owner and the beneficiary will benefit from the sugar produced obtained from the distribution of the sap according to the agreement. Whereas in the ounce method, the beneficiary will receive the benefits of the sap which is processed into coconut sugar while the owner's profit is obtained from the sugar supplied by the donor whose amount is according to the agreement.

The method of dividing the roomie into "tampan" cooperation practiced by coconut sugar producers in Karangbendo village is different. There are three types of agreements for the distribution of sap which is commonly used by coconut sugar producers in Karangbendo village, namely pump 7: 7, pump 8: 7 and "tompo" 10: 8. The kind of "tampan" that is agreed upon will determine the income that will be obtained by the beneficiary and the owner of the tree because the more the sap is obtained, the more coconut sugar will be produced so that the income to be received will be even greater. Whereas in the ounce cooperation method, the distribution is in the form of sugar, ie the tree owner will receive sugar from the donor with the provisions of 1 Ounce per coconut tree every day.

\section{SUGGESTION}

Coconut sugar producers are expected to be able to choose the right cooperation model so that no tree owners and beneficiaries feel disadvantaged. This is because the working model is "tampan" and the ounces have differences in profit sharing so that the choice of a cooperation model will determine their income

\section{ACKNOKWLEDGEMENT}

On this occasion, the researcher thanked Ms. Endah Masrunik ,. SE ,. MM. and Mr. Anam Miftahul Huda M.I.Kom as Supervisor for time, 
JOSAR, Vol. 1 No. 1 March 2019; p-ISSN: 2502-8251; e-ISSN: 2503-1155

Copyrights@ Balitar Islamic University, Blitar-Indonesia https://ejournal.unisbablitar.ac.id/index.php/josar

attention and all the guidance and direction given during the research as well as residents of Karangbendo Village who have been pleased to assist researchers in providing needed data.

\section{REFERENCES}

Bustami, Bastian dan Nurlela. 2010. Akuntansi Biaya. Edisi kedua. Jakarta: Mitra Wacana Media.

E. Kieso, Donald, Jerry j, Weygndt dan Terry D. Warfield. 2007. Accounting Principles. Jakarta: Salemba Empat.

Khotimah, Siti Ati Kusmiati dan Titin Austina. 2014. Analisi Pendapatan Pengrajin Gula kelapa dan Kontribusinya Terhadap Pendapatan Keluarga Di Desa Lojejer Kecamatan Wuluhan Kabupaten Jember. JSEP Vol. 7 No. 2.

Moleong, Lexy. 2007. Metodologi Penelitian Kualitatif. Bandung: Remaja Rosdakarya

Mugiono, dkk. 2014. Analisis Pendapatan Usaha Gula Merah Kelapa (Studi Kasus Di Desa Medono Kecamatan Kaliwiro Kabupaten Wonosobo). MEDIAGRO Vol. 10 No. 2 Hal. 22-31.

Mulyadi, 2014. Akuntansi Biaya. Edisi Kelima. Yogyakarta ; UPPAMP YKPN Universitas Gajah Mada.

Rudianto. 2012. Akuntansi Pengantar. Jakarta: Erlangga

Huda, Anam Miftakhul. Farida, N. (2018). Pengantar Ekonomi Mikro (Pertama). Pekalongan: NEM.

Huda, A. M., \& Martanti, D. E. (2018). Pengantar Manajemen Strategik 1. (J. Press, Ed.) (1st ed.). Bali:

http://books.jayapanguspress.org/index.php/publisher/article/view/18/ 18. Retrieved from http://books.jayapanguspress.org/index.php/publisher/article/view/18/ 18 